\title{
Circulating Nazi imagery \\ Wars, weapons, and generational layers of cultural remembrance
}

\author{
Laura Saarenmaa
}

Hitler's hangman killed by a bomb.

Himmler turned Gestapo into a super-efficient police force.

Local butchers did Gestapo's dirty work. ${ }^{1}$

A recent issue of the Swedish popular history magazine Historia \& Vetenskap recollects, yet again, the atrocities of the Gestapo, the secret police of Nazi Germany. The cover of the issue is dominated by a large black-and-white portrait of the uniformed Gestapo chief, Heinrich Himmler. The background to Himmler's portrait consists of a series of smaller photographs of concentration camp prisoners in their iconic striped uniform, collaging the separate images into the well-known homogeneity of the Holocaust grand narrative.

The legacy of the Second World War and the atrocities of the Gestapo have become common property in endless iterations of popular culture, with the circulation of books, magazines, feature films, television series, and documentaries, and the recirculation of Nazi narratives and images on social media. ${ }^{2}$ Circulating the memory of the Nazis, however, is hardly limited to the Internet age. Details about the Holocaust, the Gestapo, Hitler, and his fellow Nazi officers were already being consumed eagerly by mass audiences as early as the immediate post-war period. In her seminal essay 'Fascinating Fascism', Susan Sontag pondered the eroticism that surrounded fascism in popular culture and pornography in seventies America. 'Why has Nazi Germany, which was a sexually repressive society, become erotic? How 
could a regime which persecuted homosexuals become a gay turnon?'3 Sontag wondered at the erotic appeal of the Nazis in a radical American context. In the West European countries at the same time, the debate about the sexual dimensions of Nazism coincided with the rise of the political radical right and the neo-Nazi movement. ${ }^{4}$

This chapter discusses the circulation of memories of the Second World War and the Nazis in Swedish men's magazines in the sixties and seventies. The analysis charts the broader theme of war in Lektyr and Fib Aktuellt between 1965 and $1975 .{ }^{5}$ Popular men's magazines in their day, they combined pinups, nude pictures, and articles on sex with articles on crime, politics and current issues, international affairs, and military history. As has been shown in earlier studies, both magazines turned into explicit sex magazines in the late seventies. ${ }^{6}$ Until the mid 1970s, however, they were rich in detailed analyses and features on subjects other than sex. Regardless of the nude centrefolds and the articles on the art of lovemaking, it could be claimed that Lektyr and Fib Aktuellt in the sixties and early seventies were war magazines as much as sex magazines. The headlines shout of the acute danger of a third world war, reflecting the usual Cold War contradictions ('These are the frozen warzones!', 'Push the button and the war is started!'). Moreover, the magazines covered the Second World War and the cruelties of the Nazis at length and from various angles.

According to the historian Jay Winter, the second phase of the twentieth-century 'memory boom' in the sixties and seventies was in large part a form of remembrance of the Holocaust. ${ }^{7}$ In this, an important stimulus was the trial of Adolf Eichmann in 1961, which saw one of the chief organizers of the Holocaust brought to justice. Winter finds the entanglement of lived memories and media representations of wartime to be a cultural remembrance, building bridges between generations. In the print media, this remembrance has been enacted through the circulation of images, stories, and anecdotes about the Nazi villains, as well as through the recollections of the victims and the nexus of violence. Katja Valaskivi and Johanna Sumiala discuss circulation in the media as a theoretical concept that captures the full range of temporal and geographical movement. ${ }^{8}$ From a historical perspective, circulation is used to build up a set of scripts about the past and so construct a shared West European history. As a methodological tool, 


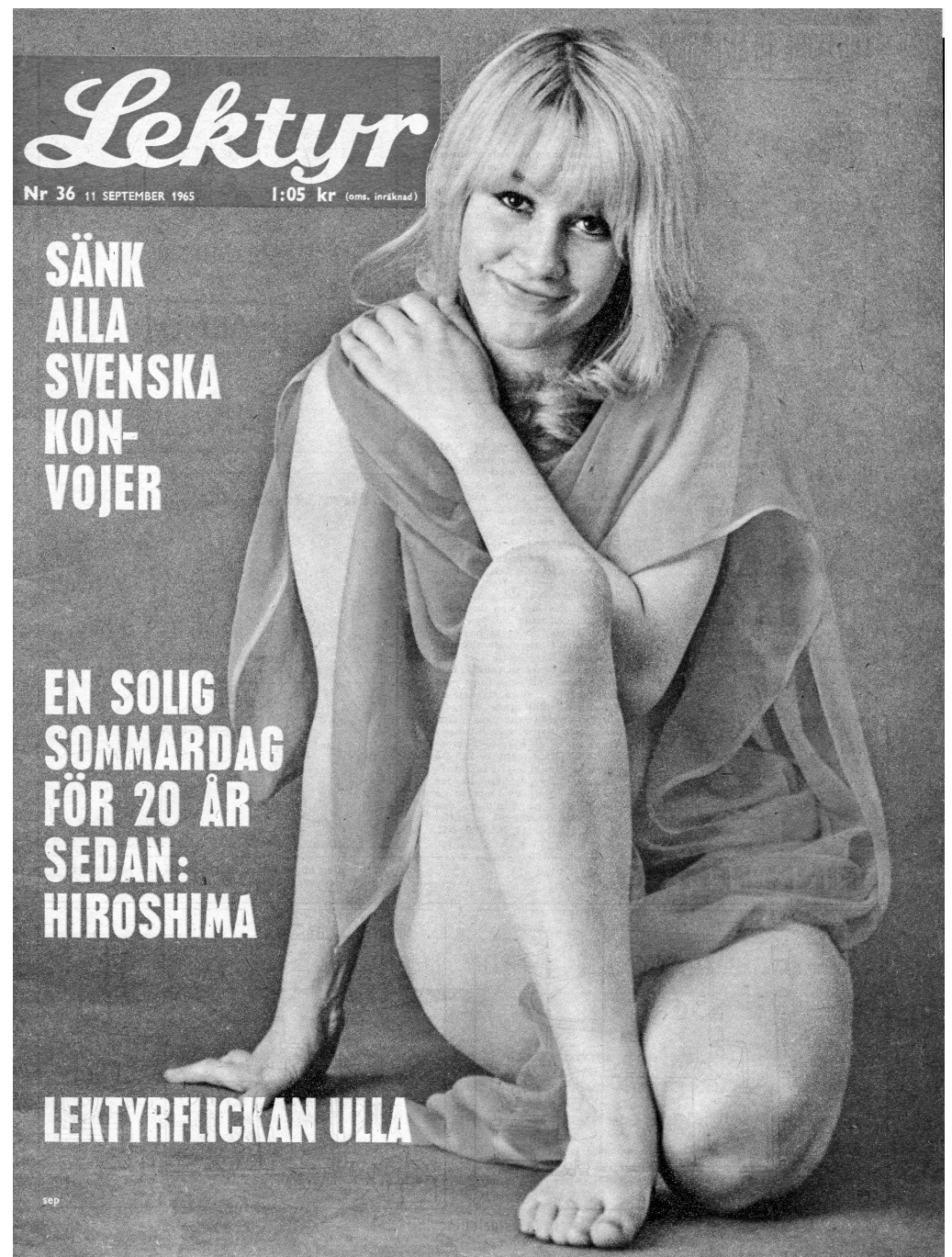

Remembering a sunny day in Hiroshima twenty years before (Lektyr 1965:36).

the concept of circulation makes it possible to study the role of the nation-state as an actor in the transnational process. ${ }^{9}$

From the early nineties onwards, Sweden's national self-image as a peaceful, non-aligned party to the Second World War has been contested evidence of people's engagement, in spite of the official policy of government-level neutrality. Popular culture has discussed 
how Sweden could function as an ally for members of the Danish and Norwegian resistance, or as an asylum for those escaping from the war, but yet remain a place where German influence and Nazi sympathies were strong. ${ }^{10}$ The debate has recently been fuelled by the rise of the extremist neo-Nazi movement (Nordiska Motståndsrörelsen) in Sweden. But why were the German Nazis and their legacy interesting in Sweden in the sixties and seventies, a time when those expressions of post-war modernity, left-wing welfare politics, social democracy, and moral liberalism, were in the ascendant? ${ }^{11}$ And why did past and current wars receive such broad coverage in Swedish men's magazines, which in the literature are held up as examples of the sexualization of culture and mainstreaming of pornography. ${ }^{12}$ Answers to these questions will be sought by focusing on Lektyr and Fib Aktuellt as arenas for war-related content-as war magazines rather than sex magazines, in other words. In so doing, I would argue that it becomes plain that Cold War political tensions and the threat of the nuclear war were inseparable elements in the Swedish zeitgeist of the sixties and seventies.

In addition to the tensions between the Cold War superpowers, both magazines showed a broad interest in the ongoing wars and conflicts in far-away places such as Vietnam, Yemen, Kurdistan, Angola, and Pakistan. In fact, Lektyr and Fib Aktuellt both covered the historical and current wars with in-depth, expert analyses, richly illustrated with photographs, maps, charts, and tables.

In a typical Lektyr feature on Cold War contradictions and the rising threat of nuclear war in 1968, the readers of the magazine were informed about the current political situation in a detailed map that identified the global conflicts with graphic symbols. In this boardgame-like display of world politics, flames marked conflicts during decolonization, a fist stood for civil war and armed conflict, and arrows denoted conflicts between neighbouring states. Rather than a complex combination of geopolitics and diplomatic interaction, world political tensions were reduced to a flat, graphic surface that could be studied analytically from afar.

Irit Rogoff has discussed maps as a cultural form that links aspirations to territorial power with truth claims. Maps provide solid bases for judgement on the grounds of an informed overview-a god's eye 
view far distant from the reality of the common soldier. ${ }^{13}$ Rather than empathy and compassion, the maps and tables give an impression that the readers of Fib Aktuellt or Lektyr were thoroughly informed and quite capable of arriving at broader conclusions.

According to the popular trope, the educational features existed merely as an excuse for the sexually explicit content of men's magazines. However, the recent scholarship on the immense success of popular history magazines instead implies that images, facts, and narratives about historical wars are in themselves a source of excitement and pleasure. ${ }^{14}$ The documentary theorist Bill Nichols has used the term epistephilia, the 'pleasure of knowing about the real world', to explain the enjoyment of documentary films. ${ }^{15}$ Nichols's idea of the pleasure of the real applies equally well to historically oriented magazine journalism that leans heavily on historical 'facts' and 'authentic' archive photography. Nichols does not discuss the gendered aspect of epistephilia, but nevertheless the pleasure of reading and 'knowing' facts about war, warfare, and military history could be defined as a distinctively male-typical pleasure. Hence the men's magazine format that combines nudes, articles on sex, and fact-oriented features on societal issues was a natural forum for the circulation of Nazi trivia and other Second World War-related material. Moreover, in the sixties and seventies the Swedish magazines seem to have found plenty of visual and written material on the Second World War and Nazis, mostly of international origin.

At the same time, the American press agencies such as Gamma, Magnum, and Associated Press were sending pictures and reports straight from the world's warzones, reflecting the internationalization of the news media business and the continued rise of the dangerous and exciting profession of the war photographer. Particularly in the case of the Vietnam War, the continuous flow of press photos of American origin could be seen as part of the cultural Cold War in Western Europe. It is likely that the archive photos of the Second World War that the Swedish men's magazines published were also bought from the international, American, British, and French press agencies, even though they are seldom credited. As Bodil Axelsson has noted of popular history magazines, when publishing archive photographs they lack the full critical insight into the historical contexts of the photographs, which 

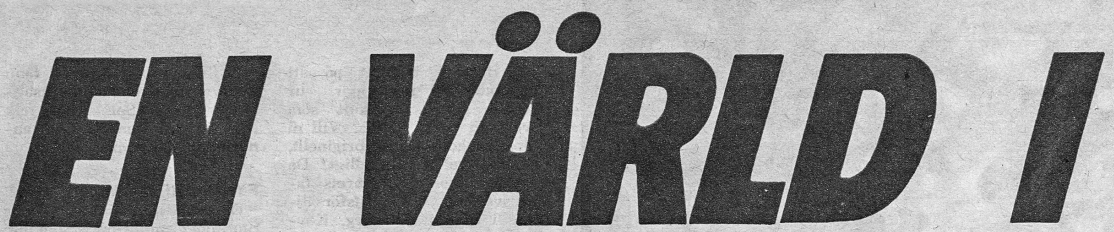

\section{I skuggan av ett kärnvapenkrig brinner oroshär}

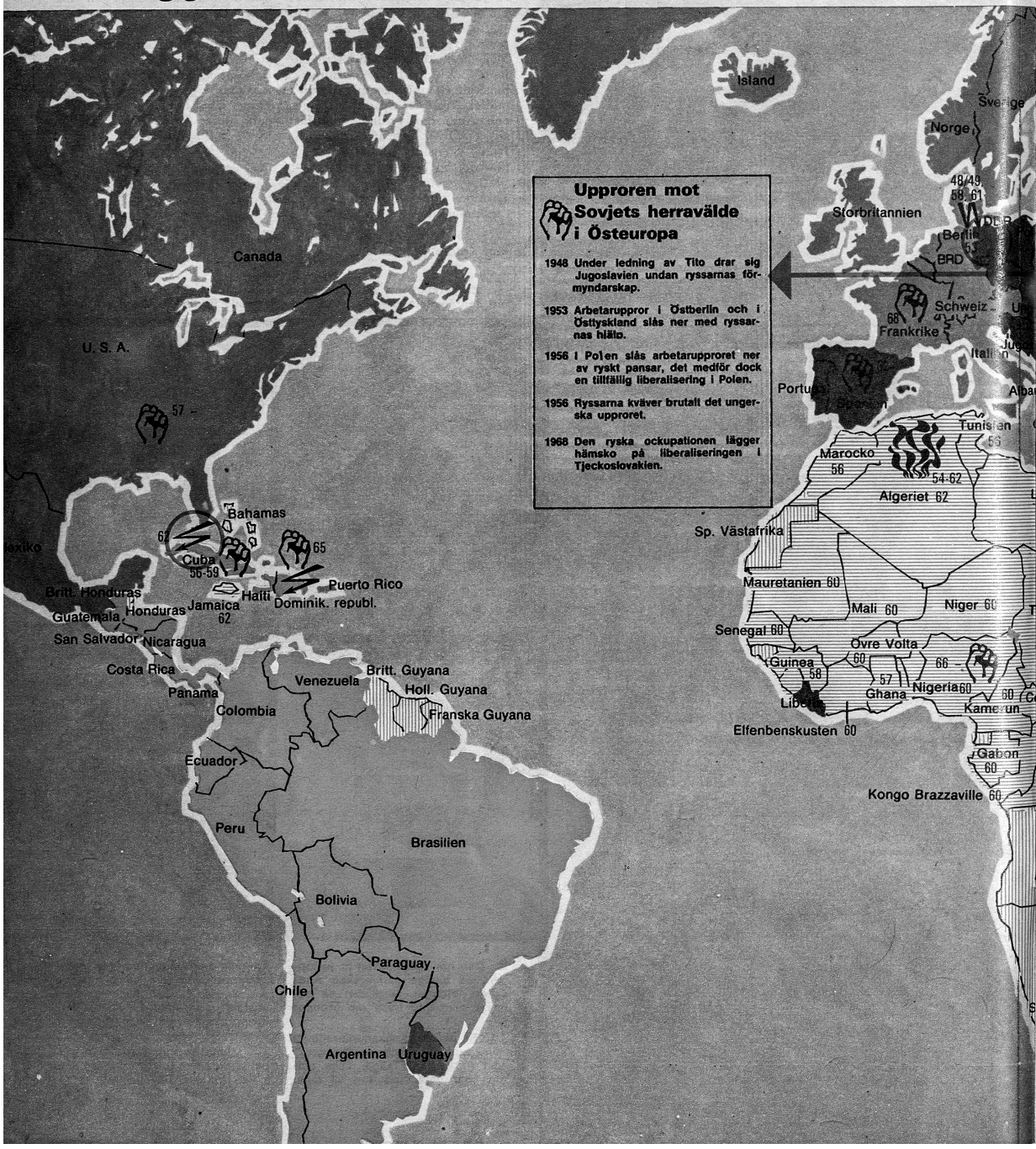

Mapping the current conflict areas in 1968 (Lektyr 1968, 51-2). 
stem from culturally and historically very different frameworks. ${ }^{16}$ The pictures themselves are represented as authentic and unambiguous testimony to the historical events that definitely took place.

\section{Eyewitness access to the Führerbunker}

In the competition for people's leisure time at a time when television was making serious inroads, popular magazines specialized in anniversaries and commemorations of historical events, typically serialized over several months, issue after issue. In its 1964 series 'The history of our time', for example, Fib Aktuellt remembered the Spanish Civil War and the early days of Franco's dictatorship, while the '20 years after the Second World War' series, which also ran in 1964, went through a number of separate wartime events and stories, from the Battle of Iwo Jima to Spandau Prison.

In the same year, Fib Aktuellt published a four-part series about the attempted assassinations of Adolf Hitler. The first focused on the attempt to blow him up with explosives hidden in brandy bottles during a flight from the Eastern Front to Berlin. ${ }^{17}$ The second focused on another attempted suicide bombing, this time at the Berlin gun exhibition, while the third part examined the 20 July Plot, which centred on a bomb hidden in a briefcase. The articles were illustrated with faded black-and-white photographs, many of them showing Adolf Hitler surrounded by his officers. There is also a photograph taken from the trial of the conspirators. No sources for the original pictures are provided. Some of the captions mention that the photograph is a still from a film, but fail to say which film. The final part of the series goes through Hitler's last days alive. Under the blunt headline 'Hitler kills himself', the piece goes through the now well-known details of the events in the Führerbunker in Berlin. ${ }^{18}$ The illustrations show Hitler having a meal in the company of Eva Braun, and reviewing his troops, a group of very young-looking soldiers lined up in front of him. There is also a photograph taken outside the Führerbunker, with no reference to the photographer or the source of the photograph.

As is characteristic of these sorts of features on the Nazis, based on archive photos, the bold headlines and layout made the maximum use of the visual effect of Hitler's name and physical persona. Other 


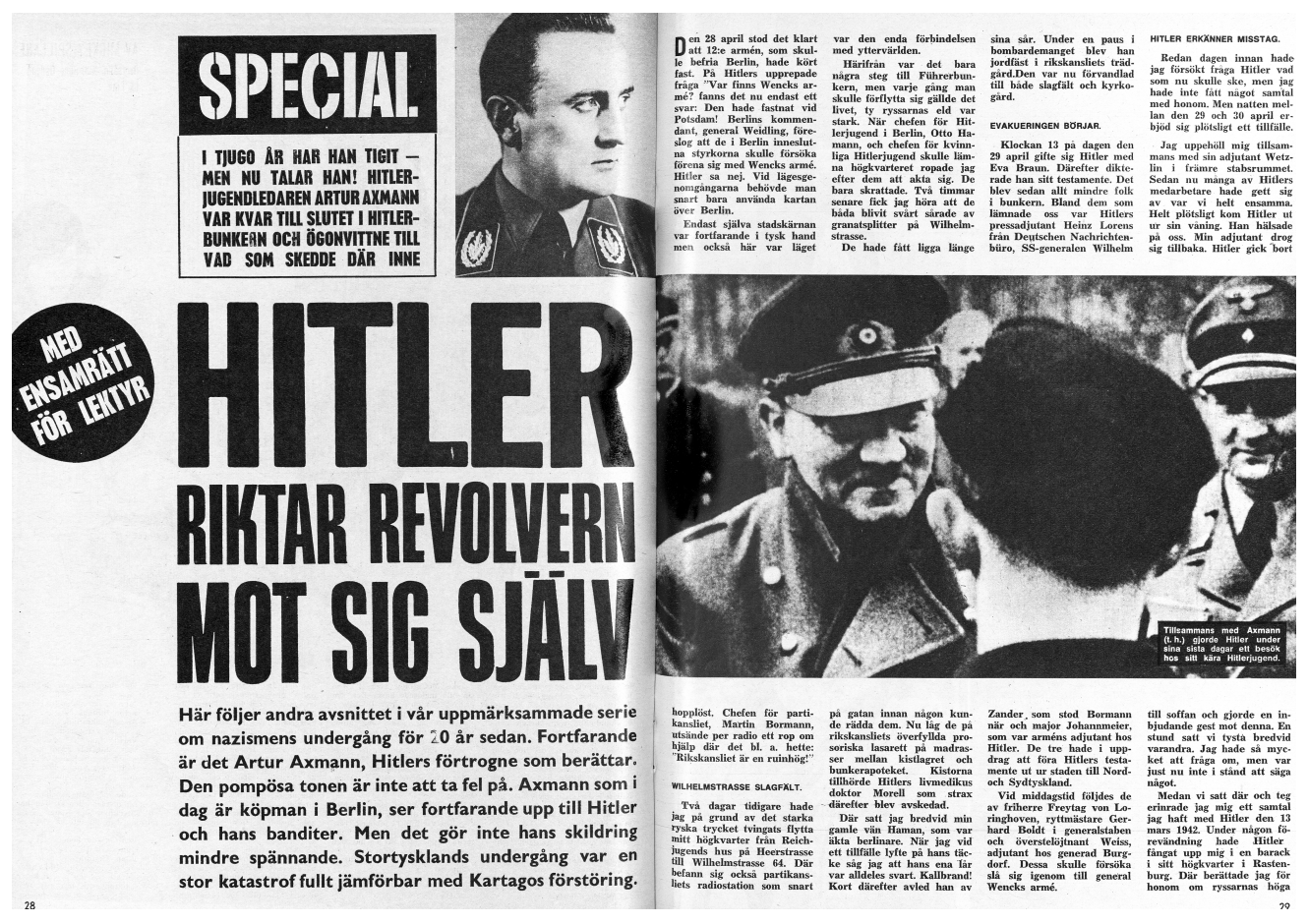

Layout maximizing the visual effect of Hitler (Lektyr 1965:24).

much-repeated features were the instantly recognizable details of the Nazi uniforms and swastikas, which were scattered across the pages in the forms of vignettes as well as archive photos.

Today, the magazine features, icons, and images are familiar to all after decades of popular cultural repetition and circulation in books, documentaries, feature films, games, and television series. Back in the mid sixties, however, the story was fresh-for many post-wargeneration readers this was often the first time it was made available in translation. One can perhaps talk of the first round of circulation, the first layer or circuit in what would prove a continuous flow over subsequent decades. The then interest in Nazi Germany was also commented on in Fib Aktuellt. According to a political columnist at the magazine, the top Nazis had 'lately come into fashion', and the recent flow of books tended to claim that the Nazis were not such 'sadistic pigs' after all, but 'pretty normal' people. 'What next? Is it to 
be expected that they will argue that Adolf Eichmann was actually a jolly good fellow, who, as a former boy scout, just happened to take his given task a bit too literally?' ${ }^{\prime 19}$

Across Europe, the Eichmann trial and recent research fed the debate about the Second World War and its meaning in the mid sixties. On one hand, the temporal distance began to make lighter comments possible. On the other, events were still so recent that there were plenty of first-hand sources available. The series on the rise and fall of the Third Reich published in Fib Aktuellt in 1965 narrated it using a first-person account by Artur Axmann, the officer who had been in charge of the Hitlerjugend. ${ }^{20}$ Presented without any references to original sources, the readers were given 'eyewitness access' to the final dramatic moments in the Führerbunker.

We entered into Hitler's room. He was seated on the sofa in his uniform: black trousers, grey jacket with the golden emblems and an Iron Cross First Class. Torso, bent to the right. Face and forehead were very pale. Over both temples ran a small blood trail. ${ }^{21}$

The eyewitness' case was backed up with uncredited photographs of Nazi officers and the locations mentioned in the text.

Photographs were also a central element in an eight-part series on Gestapo atrocities, written by the author of a recent book on the Gestapo, Jacques Delarue. ${ }^{22}$ While it is evident that the story, which was apparently wrong in some details, was again translated from English, there is no reference to the origins of the photographs that presented the shocking details of the piles of shoes collected from interned Jews, and the piles of bodies found in the mass graves at the concentration camps. The tone of the article is dramatic. 'Never, even in the time of Attila, had there been such bloodshed in Europe. Wherever the Germans arrived, hundreds of thousands of people were murdered. How could this happen? How could one of the continent's cultured nations become captivated by such cruelty?' ${ }^{23}$ The series rehearses the personal traits and characteristics of the SS officers Herman Göring, Heinrich Himmler, and Reinhard Heydrich, and presents detailed information about its organization at the heart of Hitler's governance. It claims that the German people knew very well what was going on 
in camps, but that the Gestapo had instilled such fear into people that no one dared to tell the world about it. The concluding paragraph then turns to contemporary society, articulating the primary reason for remembering the Nazi atrocities:

The nightmare is over. But is it really over for good? People's memory is short, new generations have grown up after the heyday of Nazism, and around the world similar movements are on the rise. We have seen signs of that even in this country [Sweden]. That's why knowledge of the Gestapo's crimes against humanity must be taught. New generations, who barely know who Hitler was, must be enlightened about what happened in Europe between 1933 and 1945. That is the only way to avoid the same nightmare that Hitler and his partners in crime put into action. ${ }^{24}$

The reason for remembering and recirculating Nazi imagery thus draws on the rise of the neo-Nazi movement and the need to enlighten the younger generation about the horrors of the past. The men's magazines Fib Aktuellt and Lektyr had a strong input into this knowledge production. Of course, running features on the Nazis was also an editorial policy designed to see off competing commercial magazines. In Lektyr, Hitler's name framed the most varied subjects, from the series on the German occupation of Norway, to the nuclear arms race between the Germans and the Americans. ${ }^{25}$ Even the story of Volkswagen was framed around Hitler's persona, giving the picture editor an excuse to include several photographs of Hitler in a story that actually focused on the car. ${ }^{26}$

Another much-used frame was an artificially constructed continuity between the historical past and the present. This is seen in the types of stories that viewed the past in terms of anniversaries, or which showed how past evil still lived among us. One of the early examples of that is the series about the German city of Würzburg where it was claimed a number of former members of the Nazi party held high public office, including judges, district attorneys, and the mayor. ${ }^{27}$ The story was told by a German Nazi-hunter Elmer Herterich, who had applied for political asylum in Sweden after revealing the Nazi past of the German judicial elite. The same continuity theme was also evident in the interest in Nazi descendants: the offspring of high-ranking Nazi 


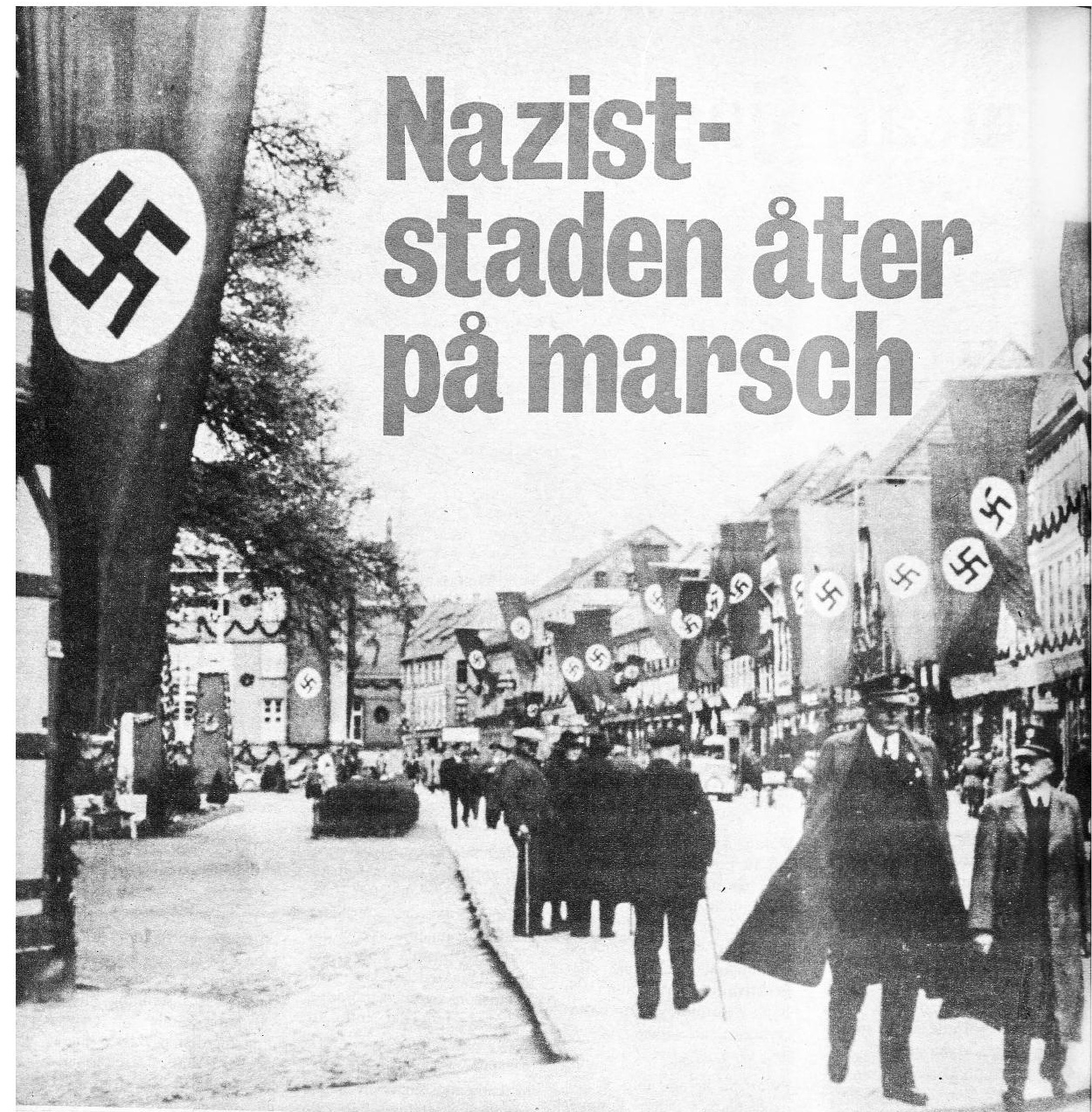

1937 i Northeim. Nazisterna drog genom gatorna med musikkår och flaggor, alla imponerades av deras ungdom och vitalitet.

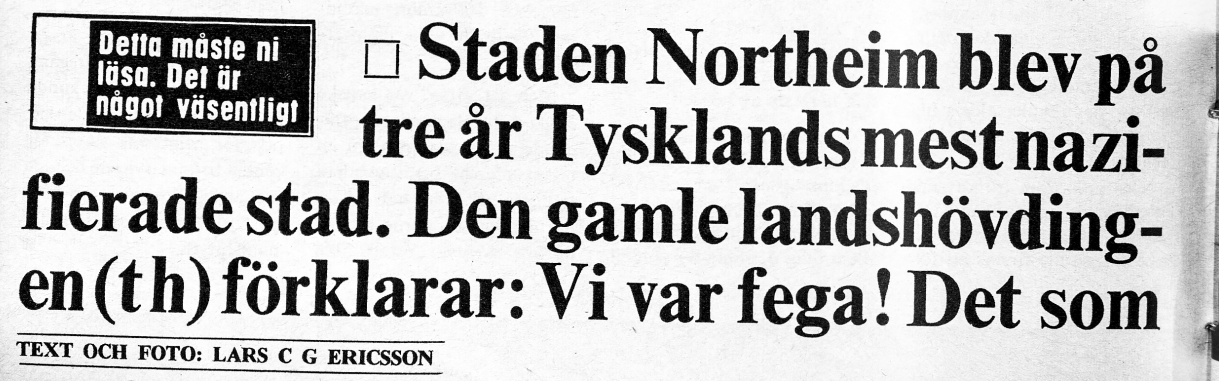

Parallelling the street view (Lektyr 1967:48 12-13). 
leaders and their current lives. ${ }^{28}$ The evil spirit of the Nazis was seen as being embodied by the Nazi officers who were still alive, above all Rudolf Hess, but also the likes of Heinz Lammerding, Gustav-Adolf Janssen, Reinhard Gehlen, and Werner Best. ${ }^{29}$

Continuity with the past was underscored in the magazine layout by the placing of historic archive photography and pictures representing the current situation next to each other. In the instance of the 1967 feature on the Nazi officer Martin Bormann ('Martin Bormann is alive!'), the blurry archive photograph of Bormann in his Nazi uniform was matched with a similar-sized portrait of an elderly Bormann in a suit and tie. Equally, in the 1973 report from Northeim, 'the most proneo-Nazi city in Germany', the layout compared the same street view in photographs from 1937 and 1967. 'There are similarities between 1937 and 1967', it was claimed, ominously.

The rise of neo-Nazism in Europe was reported in both Fib Aktuellt and Lektyr. In the mid sixties, the magazines featured the desecration of Jewish graves, the marches, and the growing political support for the neo-Nazis in West Germany. ${ }^{30}$ In the seventies it was reported to have even reached the UK and Italy. ${ }^{31}$ It was said that the headquarters of European neo-Nazism were on the small island of Ibiza, and that the movement was funded and run by old German Nazi party representatives, their ultimate goal being to build a New Germany. ${ }^{32}$ The magazines also brought to their readers' attention the fact that the European neoNazis even had Scandinavian branches, and that there were established neo-Nazi groups and organizations in Sweden as well as in Denmark. In addition to a sarcastic piece about a public speech given by a Danish 'Nordic Hitler', Lektyr ran a story about a Danish entrepreneur who was making a fortune, manufacturing and selling decorative items such as miniature busts of Hitler and swastika-decorated brass ornaments. ${ }^{33}$ In 1974, the magazine discussed the issue of neo-Nazism in a column that commented on a number of recent popular books about the philosophies of Nazi Germany. Mostly published in the UK, the columnist claimed that the books gave an alibi to current political developments and the rise of the radical right, rather than working for a critical reconsideration of the history of the Second World War: 'There is a strong interest in getting people to recognize fascist developments in our societal system. ... There is still time to react against this fascist propaganda. ${ }^{34}$ Illustrating 


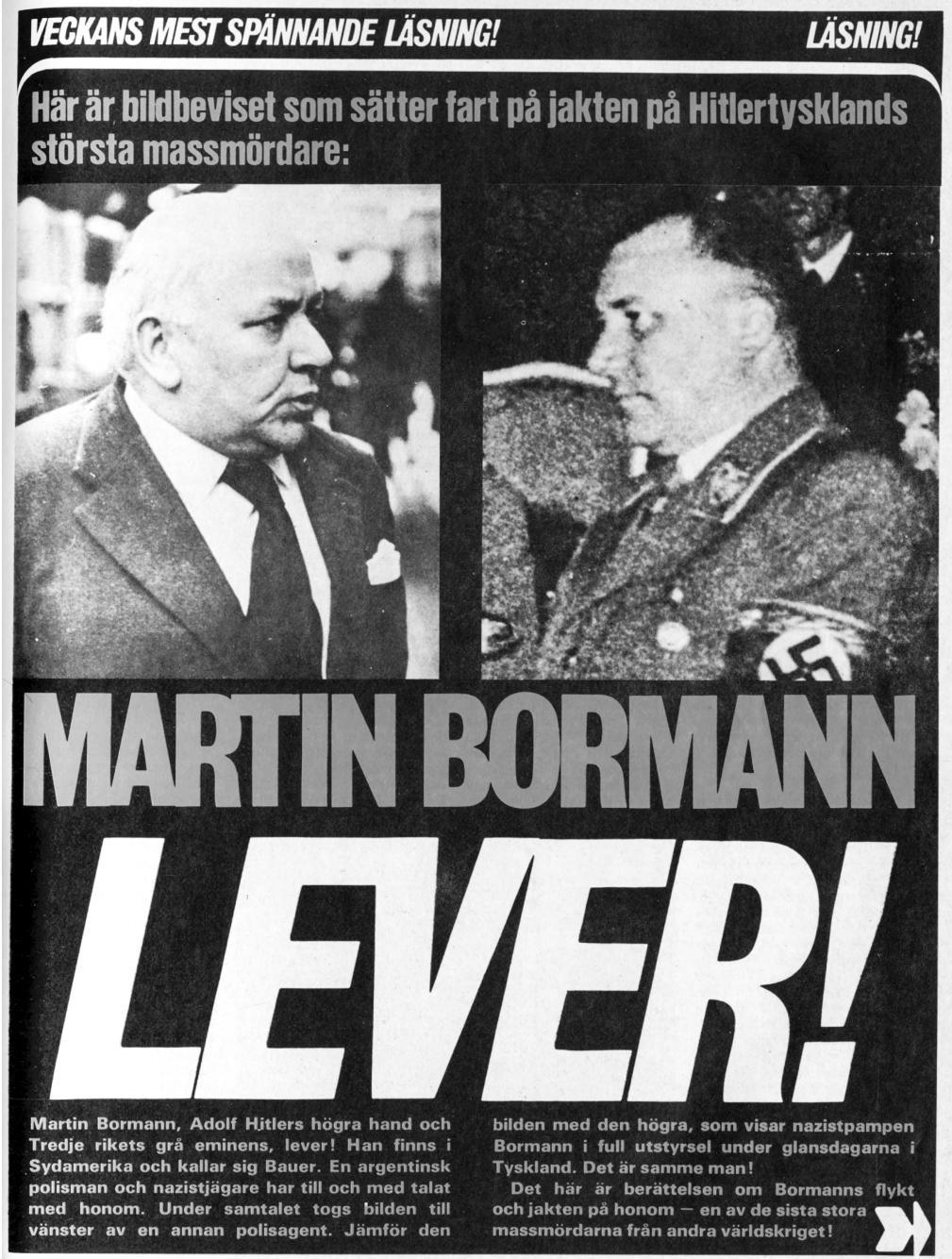

Parallelling past and present Bormann (FIB 1973:30, 21).

the somewhat confused nature of popular publishing, the column ran in Lektyr, the Swedish-language magazine responsible for circulating much of the information and anecdotes about the Nazis. That said, the column shows that men's magazines did not only blindly circulate Nazi imagery; they could occasionally subject it to critical scrutiny. Yet while this was certainly true of the left-wing magazine Fib/Kulturfronten, 
launched in 1973, it was hardly common among Sweden's mainstream men's magazines, even though the most traditional magazines were beginning to react to the changing cultural climate in the seventies by adopting the new fashion for the social reportage.

Seventies radicalism was especially evident in Fib Aktuellt, which published disapproving reportages on the Swedish Nazi movement. In 1970 the magazine paid a visit to the headquarters of Nordiska rikspartiet (the Nordic Realm Party, NRP), founded in 1956 by Göran Assar Oredsson and run by him and his German-born wife Vera. The story showcased details of this peculiar Nazi couple: how they lived, how they dressed, what their childhoods had been like. It was said that their living room was dominated by an oil painting of Hitler. According to the Oredssons, Hitler was a great man, and everything said about him and the Holocaust was untrue: 'They talk about camps in Auschwitz and Buchenwald and Dachau without presenting any reliable evidence that such places even existed.' The Oredssons insisted that the facts of the Holocaust were mere fabrications, as were all the newsreels, films, reports, and photographs published in the newspapers, because the majority of newspapers were owned by European and American Jews. The Oredssons were happy that national socialism was on the rise once more in Europe. In Sweden, this was the direct consequence of the moral decay of the Swedish people.

I can see why National Socialism arouses interest in Sweden. Just look at the strikes in prison, where the slackers and burglars complain about the quality of the food. At the same time, there are people struggling with unemployment and starving in the streets. I am not brutal, but if I were in power, those gentlemen would be treated in another manner altogether. ... Look at the drug addicts, the slobs, the long-haired hippies. If our party were in power, we would build barracks for these people so that decent, nice people would not have to see them. ${ }^{35}$

Asked about their foreign policy objectives, the Oredssons' responses were vague generalizations about national independence and military neutrality, and cutting aid to developing countries. Ultimately, it was their fanatical admiration for Hitler that was the premise of their 
political action. Fib Aktuellt, spurred into action by the Oredssons' truly outrageous claims, provided the article with 'footnotes', which gave the accepted basic facts about the Holocaust, the concentration camps, and Nazi crimes against humanity. The piece ends with a paragraph describing the reporter's relief at getting away from the Oredssons, despite the chilly weather outdoors. ${ }^{36}$

Even though the historical details about the Nazis attracted readers, both magazines shared a very real concern about the resurgent neo-Nazi movement. At Fib Aktuellt, the aversion was driven by the magazine's strong socialist orientation, as evident in its social reportage on the famine in Africa and the concurrent overproduction of food in Sweden. ${ }^{37}$ In a similar spirit, it contrasted the misery of the slums of Calcutta with the world table tennis championships hosted by the city. ${ }^{38}$ In March 1975 Fib Aktuellt announced that it had 'adopted five political prisons', and encouraged its readers to do the same: 'You can help us to rescue these prisoners by filling in the form attached to the page and sending it to the editor. ${ }^{39}$ In a fashionably left-wing vein, the magazine educated its readers about their rights to strike, and started a debate about racism in Sweden. ${ }^{40}$

Lektyr was perhaps more to the right in its coverage of national politics. It invited the conservative party leaders to explain their shadow budget in the magazine, and advised readers on the 'smartest moves' when doing their annual income tax returns. It also covered the internal disagreements and weaknesses of Olof Palme's government, implying that their readership would not much mind a change of direction in a country where the Social Democrats had held power for decades. ${ }^{41}$ Perhaps in seventies Sweden, presenting the economic policy of the conservative opposition parties was just as 'improper' and 'daring' as circulating Nazi imagery and commemorating the Second World War, given that the public sphere was dominated by discourses of social responsibility and political correctness.

\section{Disturbing information}

Fib Aktuellt and Lektyr may have taken somewhat different stances on national politics, but they had a common interest in wars and conflicts, both past and present. In the early seventies, both magazines raised 
the issue of the Swedish defence industry and the country's role in international arms deals. In 1971 Fib Aktuellt could state that Sweden was 'the biggest arms exporter in the world'. ${ }^{42}$ Large, detailed pictures filled its readers in on the international success of the latest fighter planes from Saab and tanks from Bofors, and the news that Swedish 'Carl Gustav' rifles had recently been sold to Australia, a country that was actively supporting the US in Vietnam.

In 1972, Lektyr in turn published a digest of an Italian magazine reportage about the sheer scale of the Swedish defence industry, including 'pieces of information that Swedish people may find very disturbing. ${ }^{43}$ At the time, Sweden's defence industry was still largely governed by the country's post-war policy of non-alignment, with its emphasis on maintaining a strong domestic arms industry. Arms exports were seen as a way to support the domestic arms industry, reducing procurement costs for the Swedish government, and maintaining levels of production that would allow Sweden to increase supplies if it were to be drawn into a conflict. During the seventies, Sweden accounted for 0.3 per cent of global arms transfers and was the twelfth largest exporter. ${ }^{44}$ The Fib Aktuellt article in question expected there to be public unease at the figures, suggesting that the public was unaware of the scale of Swedish exports. This does not mean that the issue had not been covered by the mainstream media-on the contrary, at least some news and opinion pieces were published in the daily papers - but it could still be argued that with their sensationalist aesthetic and full-colour spreads, the men's magazines drew public attention to the arms industry and the political reasoning behind Sweden's soaring arms exports. At the same time as the magazines increased public awareness of global conflicts, they reminded readers of Sweden's complicity. Their tone tended towards the sensationalist: Fib Aktuellt reported that Swedish machine guns had been used in the 1973 coup in Chile, and published photographs were said to support the claim, and it used the same accusing tone to report that Sweden was selling dumdum bullets, generally forbidden for military use, to the Kurdish guerrillas fighting in Iraq in $1975 .{ }^{45}$ In the same year, it carried a story about Swedish Scania trucks being used to run grenades for the guerrilla fighters in the Kurdistan mountains. ${ }^{46}$

The mix of moral dilemmas, financial journalism, and eroticized 
excitement about armed conflicts and the arms trade found here is in broad agreement with earlier analyses of the political climate in Cold War Sweden, which was characterized by discourses of fear, social responsibility, and political correctness. The daring attitude characteristic of men's magazines offered some scope to raise public awareness and fuel debates on social issues. Lektyr and Fib Aktuellt seem to have been primarily concerned with Sweden's connivance in the international wars and conflicts of the day.

The circulation of Nazi imagery and preoccupation with the Second World War was more part of an international, Western trend. In the Swedish context, given the interest in current armed conflicts, the recirculation of Nazi atrocities kept the memory of the Second World War alive and perhaps shaped public opinion to be more favourable towards a strong defence industry. By making much of interconnectedness and comparing past with present, the magazines at least increased historical awareness. Another explanation, though, might perhaps be the interests of the magazine's young male readership. As Fia Sundevall has pointed out, Fib Aktuellt and Lektyr were particularly popular leisure-time reading among Swedes doing military service. ${ }^{47}$ In the sixties and seventies, the circulation of Nazi imagery and Second World War stories was driven in part by an intergenerational transfer of information to younger readers, who did not have personal memories of the war. By this circulation, the next generation were addressed as members of the Western cultural community, and invited to share in Western Europe's historical legacy, but in their own language.

These seemingly disparate topics-Nazi officers, global Cold War tensions, Swedish arms exports, the rise of neo-Nazism-were in fact all situated in an overarching sensationalism that characterized the magazines in question. All the topics were similarly shocking; all were covered in a similarly dramatic manner, although not with similar modes of representation. As journalistic products, the magazines were platforms for war-related material of all sorts. What they were not were sharply defined niche publications. Rather than one strident editorial voice, there was a chorus of voices as numerous journalists and photographers used their personal connections and networks to promote their personal and professional interests in their published work. This polyphony also explains the broad mix of high-quality 
war photography and historic photographs, and detailed maps and charts that presented global conflicts in game-like scenarios, studied analytically from afar.

Women and their physical qualities were also studied from afar in the magazines. Women did not feature as subjects, agents, or public figures, and the changing role of women was not discussed. All in all, women's voices were seldom heard in Lektyr and Fib Aktuellt, apart from in inconsequentially saccharine interviews-or freaks such as Vera Oredsson. Given that this was the age of women's rights and gender equality in the Western countries, the omission is striking. In contrast, American Playboy Magazine included debates about women's liberation, and invited famous feminist activists to explain their ideas and express their dislike of the magazine in the magazine. In Sweden, women attacked the sexist imagery of the men's magazines by burning Lektyr's and Fib Aktuellt's sandwich boards. ${ }^{48}$ Yet despite this, the magazines kept on with their countercultural male space, which could countenance the horrors of Nazism, but exclude the horrors of female subjectivity.

In the seventies literature, the eroticism of the Nazi images was seen as tapping into a fear of the feminine. As Klaus Theweleit wrote in Männenphantasien, published in Germany in 1977 and 1978, fascist fantasy, with its order, discipline, and clarity, pushed away the anxiety and messiness associated with women and the feminine, and war, as a male-centred enterprise, was accordingly felt to be the wellspring of pure, unrestrained manliness. ${ }^{49}$ Even Susan Sontag concluded as much when looking at the Nazified pornography and sexual metaphors of fascist leadership..$^{50}$

Read in relation to their war reportages, the circulation of Nazi imagery in Swedish men's magazines owed more to Cold War political contradictions than to gender politics. The seventies saw a growing interest in war and conflict in terms of the international politics of peacekeeping and the Swedish defence industry, and at the same time there were growing concerns about the rise of neo-Nazism in Italy, France, Germany, Britain, Denmark - and Sweden. Keeping alive the memory of the Second World War and the horrors of the Nazi regime constructed a proximity between a historically and geographically distant past and the present, and showed their interconnectedness 
with the current political concerns, at the same time winning over Swedish hearts and minds to the idea of a strong defence industry and arms exports.

The entangled narratives of wars past and present, the maps, charts, and Cold War framework, all called for an analytical and distant reading rather than an empathic one. The same went for the endlessly recirculating images of Nazi officers, which tended to highlight the personality and perspective of those acting rather than those suffering. From the glossy cover of Historia \& Vetenskap, Heinrich Himmler stares out at us, all vigorous pose and military fastidiousness, while behind him the victims of the Holocaust blur into an unrecognized, unrecognizable mass, crushed by the overwhelming superiority of that one Nazi. Perhaps the endless fascination with Nazi personalities is right there: in our inability to look at their individual victims and their personal histories.

\section{Notes}

1 Historia \& Vetenskap, 2 (2017).

2 Petra Rau, Our Nazis: Representations of fascism in contemporary literature and film (Edinburgh: EUP, 2013); Eva Kingsepp \& Tanja Schult (eds.), Hitler für alle: Populärkulturella perspektiv på Nazityskland, andra världskriget och förintelsen (Stockholm: Carlssons, 2012).

3 Susan Sontag, 'Fascinating Fascism', New York Review of Books, 6 Feb. 1975, www.nybooks.com/articles/archives/1975/feb/o6/fascinating-fascism/ (accessed 6 Apr. 2017).

4 Torsten Bergmark \& Birgitta Bergmark, Det svarta spåret: En bok om nyfascismen i Italien (Stockholm: Arbetarkultur, 1975); Johan Östling, 'Massor av män: Fascismen som fantasi i 1970-talets politiska kultur', in Marie Cronqvist et al. (eds.), 1973: En träff med tidsandan (Lund: Nordic Academic Press, 2008), 103-104.

5 The combined circulation of Lektyr and Fib Aktuellt rose from 500,000 to 540,000 sold copies during the period in question here, 1965-1975; see Klara Arnberg, Motsättningarnas marknad: Den pornografiska pressens kommersiella genombrott och regleringen av pornografi i Sverige 1950-1980 (Stockholm: Sekel, 2010), 273.

6 Klara Arnberg \& Mariah Larsson, 'Benefits of the in-between: Swedish men's magazines and sex films 1965-1975', Sexuality \& Culture, 18 (2014), 310-30; Anja Hirdman, Tilltalande bilder: Genus, sexualitet och publiksyn (Stockholm: Atlas, 2006).

7 Jay Winter, Remembering war: The Great War between memory and history in the twentieth century (New Haven: Yale University Press, 2006), 18. 
8 Katja Valaskivi \& Johanna Sumiala, 'Circulating social imaginaries: Theoretical and methodological reflections', European Journal of Cultural Studies 17/3 (2014), 229-43.

9 Ibid. 234.

10 Louise Nilsson, 'Kriget som underhållning: Andra världskriget och nazismen i svenska deckare', in Kingsepp \& Schult, 2012), 193-218.

11 Johan Östling, 'The rise and fall of small-state realism: Sweden and the Second World War', in Henrik Stenius et al. (eds.), Nordic narratives of the Second World War: National historiographies revisited (Lund: Nordic Academic Press, 2011), 127-47.

12 Arnberg \& Larsson 2014; Hirdman 2006.

13 Bodil Axelsson 'History in popular magazines: Negotiating masculinities, the low of the popular and the high of history', Culture Unbound, 4 (2006), 275-95.

14 Marianne Sjöland, Historia från tidskriftsredaktionen: En komparativ studie av Populär Historias och History Todays historieskrivning (Lund: Studia Historica Lundensia, 2016); Susanne Popp et al. (eds.), Commercialized history: Popular history magazines in Europe: Approaches to a historico-cultural phenomenon as a basis for history teaching (Frankfurt: Peter Lang, 2015); Axelsson 2006.

15 Bill Nichols, Representing reality: Issues and concepts in documentary (Bloomington: Indiana University Press, 1991), 178-9.

16 Axelsson 2006, 285.

17 'Mörda Hitler', Fib Aktuellt 1964:27, 10-13, 28. The series was composed by Bertil Lagerström, but the copyrights were owned by Stephan Richter, supposedly the original author of the piece.

18 'Attentatsmännen beredda att betala med sina liv', Fib Aktuellt 1964:28, 26-27, 44; 'Generalerna dog men Hitler överlevde', Fib Aktuellt 1964:29, 32-35, 42; 'Hitler tar sitt liv', Fib Aktuellt 1964:30, 28-29, 44.

19 'Himmler var "beskedlig", Hitler ett militärt geni', Fib Aktuellt 1965:22, 30. Column by Olof Lennart Praesto.

20 'Hur Hitlers Tredje Rike gick mot sitt Ragnarök', Lektyr 65:23, 3-5, 33-5; 'Hitler riktar revolvern mot sig själv', Lektyr 1965:24, 28-9, 36; 'Bormann och jag flydde granatregn', Lektyr 1965:25, 10-11, 39.

21 'Hitler riktar revolvern mot sig själv', Lektyr 1965:24, 24.

22 'Gestapo-Skräckens ministerium', Lektyr 1965:31, 8-11, 34, 36; 'Söndra tortera mörda', Lektyr 1965:32, 5, 6-7, 40-41; 'En djävul i dödskallemössa', Lektyr 1965:33, 10-11, 12-13, 38-9; 'Mord och tortyr dygnet runt', Lektyr 1965:34, 10-11, 12-13, 34-5; 'Röhm gräver sin egen grav', Lektyr 1965:35, 6-7, 8-9, 33; 'De vadade i floder av blod!', Lektyr 1965:36, 12-13, 38-9; 'När Europa darrade', Lektyr 1965:37, 9, 10-11, 34-5; 'Vilddjuret biter i gräset', Lektyr 1965:38, 10-11, 34-5.

23 Lektyr 1965:36, 12: 'Aldrig, inte ens under Attilas tid hade en sån blodström brutit ut över Europa. Vart tyskarna än kom mördades hundratusentals människor på det mest bestialiska sätt. Hur kunde det ske? Hur kunde ett av världsdelens kulturfolk gripas av en sådan totalitär grym ondska.'

24 'Vilddjuret biter i gräset', Lektyr 1965: 38, 35.

25 'Norska Finnmark i flammor', Lektyr 65:9, 4-5, 38; 'Söder åt eller dö!', Lektyr 
65:10, 9, 10-11, 35; 'Blod och tårar i Halden', Lektyr 65:49, 18-19, 38; 'Hitler kunde ha varit först med atombomben', Lektyr 1967: 21, 6-7, 40; 'Kapplöpning om tyskarnas reaktor', Lektyr 1967:22, 22-3; 3; 'Kapplöpningen om atombomben', Lektyr 1967:23, 10-11.

26 'Den fantastiska sagan om Volkswagen', Lektyr 70/2, 8-9, 10-11, 50.

27 'Skuggan av Hitlers Hakkors', Lektyr 1964:34, 16-21, 46; 'Här är beviset-Men nazisterna segrade ändå, Lektyr 1964:35, 4-5, 44.

28 'Hitler fick barn med Eva Braun!', Fib Aktuellt 1965:21, 21; 'Vad blev det av nazistledarnas barn?', Fib Aktuellt 1966:1, 22.

29 'Han [Hess] utförde andra världskrigets galnaste företag', Lektyr 1971:30, 34-5, 36-7, 38-9, 54; 'SS-Generalen Fritz Lammerding: I denna idyll lever massmördaren', Lektyr 1971:7, 34-5, 36-7, 44; 'Gustav Adolf Jansen-Hitlers privatsekreterare som blev diplomat', Lektyr 1971:20, 2-3, 4-5; 'Dr Werner Best och två av hans Gestapo män står nu inför rätta för att ha dödat 10,000 människor. De kastade upp barn i luften och sköt prick på dem', Lektyr 1972:31, 38-9, 46; 'Århundradens spion Reinhard Gehlen: En av Hitlers närmaste män', Lektyr 1972:20, 52-3, 54-5.

30 'Terror 65: Aktion Hakkors', Fib Aktuellt 1965:32, 24-5, 26, 45; 'Blir han den nye Hitler?', Fib Aktuellt 1966:50, 22; 'Nazist-staden åter på marsch', Fib Aktuellt $1967: 48,12-13,14-15,54$.

31 'Bomber, terror och död värvar anhängare till fascismen. Den italienska fascismen marscherar igen', Lektyr 1974:28, 36-7, 38-9.

32 'Härifrån ska nynazister erövra världen!', Lektyr 1971:49, 34-5, 36-7.

33 'Här talar Nordens Hitler', Lektyr 1970:22, 16-17; 'Dansk utnyttjar Nynazismen', Lektyr 1971:45, 33.

34 'Nazismen- Är den på väg tillbaka?', Lektyr 1974:6, 16. The column was written by Tony Rosendahl, a freelance journalist with a conviction for fraud, who was author of a number of reportages on international politics and armed conflict published in Lektyr in the seventies.

35 'Sveriges Nazister håller möte i högkvartetet!', Fib Aktuellt 1970:47, 30-1, 32-3.

36 In 1974 Fib Aktuellt published another interview with the Oredssons about the clash between the two competing Swedish neo-Nazi parties, Nordiska Rikspartiet and Kommunistfientliga Demokratisk Allians, DA. In the illustration, Vera Oredsson posed again in front of the Hitler portrait.

37 'På den här sopstationen brände en svensk kommun 700 kilo kött. Samtidigt svälter tusentals barn till döds i tredje världen', Fib Aktuellt 1974:44, 18-19, 60.

38 'En indisk familj och deras bostad i världens fattigaste stad. Här samlas världseliten i bordtennis', Fib Aktuellt 1975:6, 3-4, 5-6, 6-7, 8-9.

39 'Fib Aktuellt har adopterat fem politiska fångar. Här får du möta två av dem', Fib Aktuellt 1975:12, 20-1, 58.

40 'Din rätt att strejka!', 'Här är arbetsgivarnas hemliga strejkbibel!', Fib Aktuellt 1975:11, 1, 68-9; 'Karl Bolay om svenskt rashat: "Visst finns det rashat i Sverige", Fib Aktuellt 1975:21, 58-9, 60-1.

41 'Lektyr avslöjar: Palmes regering splittrad i tre politiska partier', Lektyr 1972:51, 12-13, 53; 'Lektyr avslöjar de politiska frågorna som kan störta regeringen Palme', Lektyr 1974:2, 22-3. 
42 'Sverige är världens största vapenexportörer', Fib Aktuellt 1971:11, 12-13, 14-15.

43 'En igelkott som har ett av världens starkaste försvar', Lektyr 1972:11, 42-3, $44-5,62$.

44 https://www.sipri.org/sites/default/files/2016-03/Current-trends-in-the-international-arms-trade-and-implications-for-Sweden.pdf.

45 'Svenska K-pister används i terrorn mot arbetarna i Chile', Fib Aktuellt 1973:45, 6-7, 66; 'Förbjudet att använda mot människor!', Fib Aktuellt 1975:15, 2-3, 4-5.

46 'Vi körde mjöl- och granater', Fib Aktuellt 1975:15, 10-11, 12-13, 14, 56.

47 Fia Sundevall, 'Porr i vapenskåpet och bögkompani på Gotland: sexualitet i lumpen', in Anna Maria Forssberg \& Klas Kronberg (eds.), Lumpen: från mönstring till muck (Stockholm: Atlantis, 2014), 150-171.

48 Arnberg 2010, 237-61.

49 Östling 2008, 106-107.

50 Sontag 1975.

\section{References}

Arnberg, Klara, Motsättningarnas marknad: Den pornografiska pressens kommersiella genombrott och regleringen av pornografi i Sverige 1950-1980 (Stockholm: Sekel, 2010).

- - \& Mariah Larsson, 'Benefits of the in-between: Swedish men's magazines and sex films 1965-1975', Sexuality \& Culture, 18 (2014), 310-30.

Axelsson, Bodil, 'History in popular magazines: Negotiating masculinities, the low of the popular and the high of history', Culture Unbound, 4 (2006), 275-95.

Bergmark, Torsten \& Birgitta Bergmark, Det svarta spåret: En bok om nyfascismen i Italien (Stockholm: Arbetarkultur, 1975).

Hirdman, Anja, Tilltalande bilder: Genus, sexualitet och publiksyn (Stockholm: Atlas, 2006).

Igelstam, Lars, Vapen i Sverige och världen: Delrapport från projektet mellan förbud och exportfrämjande: Om vapenexport från Sverige (Linköping: Linköpings universitet, 2010).

Kingsepp, Eva \& Tanja Schult (eds.), Hitler für alle: Populärkulturella perspektiv på Nazityskland, andra världskriget och förintelsen (Stockholm: Carlssons, 2012).

Nichols, Bill, Representing reality: Issues and concepts in documentary (Bloomington: Indiana University Press, 1991).

Nilsson, Louise, 'Kriget som underhållning: Andra världskriget och nazismen i svenska deckare', in Kingsepp \& Schult 2012, 193-218.

Östling, Johan, 'Massor av män: Fascismen som fantasi i 1970-talets politiska kultur', in Marie Cronqvist, Lina Sturfelt \& Martin Wiklund (eds.), 1973: En träff med tidsandan (Lund: Nordic Academic Press, 2008), 101-113.

-_ 'The rise and fall of small-state realism: Sweden and the Second World War', in Henrik Stenius, Mirja Österberg \& Johan Östling (eds.), Nordic narratives of the Second World War: National historiographies revisited (Lund: Nordic Academic Press, 2011), 127-47.

Popp, Susanne, Jutta Schumann \& Miriam Hannig (eds.), Commercialized history: 
Popular history magazines in Europe: Approaches to a historico-cultural phenomenon as a basis for history teaching (Frankfurt: Peter Lang, 2015).

Rau, Petra, Our Nazis: Representations offascism in contemporary literature and film (Edinburgh: EUP, 2013).

Rogoff, Irit, Terra infirma: Geography's visual culture (London: Routledge, 200o).

Sjöland, Marianne, Historia från tidskriftsredaktionen: En komparativ studie av Populär Historias och History Todays historieskrivning (Lund: Studia Historica Lundensia, 2016).

Sontag, Susan, 'Fascinating Fascism', New York Review of Books, 6 Feb. 1975, www. nybooks.com/articles/archives/1975/feb/o6/fascinating-fascism/ (accessed 6 Apr. 2017).

Sundevall, Fia, 'Porr i vapenskåpet och bögkompani på Gotland: Sexualitet i lumpen' in Anna Maria Forssberg \& Klas Kronberg (eds.), Lumpen: Från mönstring till muck (Stockholm: Atlantis, 2014), 150-71.

Valaskivi, Katja \& Johanna Sumiala, 'Circulating social imaginaries: Theoretical and methodological reflections', European Journal of Cultural Studies, 17/3 (2014), 229-43.

Winter, Jay, Remembering war: The Great War between memory and history in the twentieth century (New Haven: Yale University Press, 2006). 